\title{
MTDPNA in Non-Oil International Organisations in Libyan Post Crisis
}

\author{
Ahmed Younes (PhD Student) $)^{1}$, Jim Stewart (Professor) ${ }^{2} \&$ Niki Kyriakidou (Doctor) ${ }^{3}$ \\ ${ }^{1}$ Leeds Metropolitan University, UK \& Tripoli University, Libya \\ ${ }^{2}$ Leeds Metropolitan University and Coventry University, UK \\ ${ }^{3}$ Leeds business school, Leeds Metropolitan University, UK \\ Correspondence: 10 Anderson Avenue, Post code: LS8 5EG, Leeds, UK. E-mail: A.Younes@leedsmet.ac.uk, or \\ Ahmed_younes35@yahoo.com
}

Received: December 3, 2012

Accepted: December 26, 2012

Online Published: January 7, 2013

doi:10.5430/bmr.v2n1p18

URL: http://dx.doi.org/10.5430/bmr.v2n1p18

\begin{abstract}
This paper investigates how non-oil international organisations (NOIO) in Libyan post-crisis assess management training and development programme (MTDP) needs. The current situation of MTDP needs assessment and factors that may influence MTDP are investigated. Questionnaire was distributed to (150) managers from nineteen NOIO. We find that performance and experience were the most common MTDPNA measures. Likewise, poor performance, lack of knowledge, and introduction of new work methods were the most common MTDPNA indicators. Customer dissatisfaction, poor service quality, low profitability, and lack of knowledge were also found that have a positive or negative influence on MTDPNA such as; organisational sectors, size, and ownership. Customer dissatisfaction, poor service quality, low profitability, and lack of knowledge were the most used positive indications for the hotel sector, services, manufacturing, and joint venture organisations. Our findings suggested that MTDPNA should be conducted at different times, and different methods should be used.Also, MTDPNA decisions have to be based in a systematic way rather than targeting single or a group of individuals, and have to be delivered equally.
\end{abstract}

Keywords: management training and development programmes (MTDP), MTDP needs assessment (MTDPNA), non-oil international organisations (NOIO), Libyan Post Crisis (LPC)

\section{Introduction}

For years, training needs analysis has beenmainly about conducting an effective TDP, also training needsare assessed to identify who needs to be trained and the type of training programme they require (Al-Khayyat, 1998; Holten et al., 2000). During the last decade, there is no doubt that training needs assessments are more effective and successful, as the concept of training needs assessment has changed from being a shift from training outcomes to training as a vital business strategy for organisations (Earley and Peterson, 2004; Stone, 2009). Therefore training needs assessment is conducted to assess employees or managers strengths and weaknesses before delivering the training and developing programme (Graf, 2004b; Littrell and Salas, 2005; Tarique and Caligiuri, 2004). Also, training and development programmes which include methodical assessment may decrease costs and time of the programme, as they will be able to control the opportunity and sort of training and development which is essential. (Selmer, 2000)

In this paper, we intend to investigate management training and development programme needs assessment (MTDPNA) in Libyan post-crisis (LPC). An effective training programme is an important key stage undertaken by any organisations in determining the type of T\&DP to be provided to their employees or managers.And also to ensure that resources are utilised efficiently, to provide some important information in regards to the topic in the country of study (Libya). As a first step, we present the importance of NOIO in Libyan post-crisis. Second we review literature based on MTDP and MTDP in Libya in particular. MTDP needs assessment in Libya and the Arab region. However very few studies were found in regards to MTDPNA in Libya. Third we distributed questionnaires to all managerial level in 19 NOIO in Libya. Based on our results, we provide suggestions for NOIO in LPC to conduct MTDPNA at different time and to use different methods, and all department can be involved in making decision, as well as MTDPNA can be delivered equally.

\section{The importance of NOIO in LPC}

In today's global business environment and dynamic markets, organisations are moving to increase their profit and expand their market outside their region. They also seek to locate their strategy in developing countries to reduce 
their production costs (Jiraphan, 2000). In addition, according to Moran (2005, quoted in Gamal, 2008), foreign investment helps to overcome many local economic problems.

Therefore, for many years Libya and some Arab countries have been the largest and the most active market for foreign organisations, particularly when they discovered oil (Enshassi, \& Burgess, 1990).

However, Eid \& Fiona (2003) found that, the Arab countries still receive less Foreign Direct Investment compared to world FDI flows, which mean that FDI plays small part within the Arab region. They suggested that the Arab region and Libya is part of it, have to take some crucial steps to encourage FDI to come to the region and do full business by focusing on three critical areas: public institutions, physical infrastructure, and human resource development. Certainly, by continuing the development process and implementing these three critical areas, the Arab countries can successfully increase investment for long-term benefits (Eid, \& Fiona, 2003).

In this regards, Libya is trying to play a crucial role in enticing NOIO to come to Libya and to do a full range of economic activities in order to achieve the highest levels of national growth with a greater access to global markets, and in the hope of raising living standards.

Therefore, steps have been taken by the Libyan Government to promote investment in the non-oil sector, which will be on one hand to create more jobs and to increase minimum wages, labour safety standards, etc. (Hartungi, 2006), and on the other hand to reduce the official unemployment rate which is running in excess of $30 \%$ (Political Risk Yearbook: Libya Country Report, 2009).

On achieving that, the government implemented Law No5 in 1997 and its special provisions in 2003, to encourage foreign organisations to enter Libya by establishing branch offices, joint ventures, and representative offices or full business. (Law No. 5, 1997 for Promotion of Investment of Foreign Capital); Amended by (Law No. 7, 2003); and with the finally amended to (Law No. 9, 2010)

According to a speech by the Secretary of General People's for Economy (and Minister of Economy) in the International Conference on Trade and Investment on Tuesday, 30 March 2010 in Tripoli, "Libya made 150 billion diners for the development of infrastructure, pointing to the availability of all the investment opportunities in various fields in Libya" (http://www.libyaalyoum.com)

Moreover, a head of strategic projects in the Council for Privatization and Investment, in an interview with Reuter's news agency, indicated that Libya will shift half of the country's economy to the private sector within ten years, creating opportunities for non-oil-international organisations to come to Libya and do business.

Additionally "We prefer that the state withdraws from all economic activities and focuses on the formulation of Law and Regulations". The reason for the government doing this is not because the country needs wealth, as the country has huge wealth in terms of oil and money, but to attract private sector expertise to create jobs and technology and to improve the opportunities for Libyan workers, as well as to reduce the country's dependence on oil and gas (cited by http://ara.reuters.com).

\section{MTDP}

Training programmes aim to improve and increase the existing employee's skills and performance, while developing programme targets to increase employees or mangers capabilities in respect to transfer to future position or job. (Dowling and Welch, 2004)

MTDPs are described as a way of producing any opportunity for learning that helps to assist the process of achieving change (Whetherly, 1998). Stewart (1996, quoted in Younes, 2007, p. 25) and De Silva, (1997) point that; training and development are considerate for the purpose of the organisation, which has the aim of ensuring that the contribution of both individuals and groups to the accomplishment of the organisation objectives is maximised throughout the development of knowledge, skills and attitudes.

All development and training programmes should be tailored to meet both the needs of the individual and that of the organisation. MTD is a long-range process that requires time and results cannot be expected quickly (Reitsma, 2001).Therefore, any organisations that use MTD as a strategic implement, is to help the organisation meet its short and long-term targets (Reitsma, 2001). Besides, training and development can help any organisation in optimising the use of human resource, which further helps workers to attain organisational and individual goals.Basically training can be seen as an activity that modifies employee's behaviour which leads them to improve the skills for doing their work. Development is a long process that increases the skills and abilities to do a particular job (Piyali et al., 2011). As a practice, management training helps to modify employee's performance at work, in addition to the manager learning values themselves (Anderson, \& Gilmore, 2010).Bass and Vaughan (1966) argue that people 
cannot be brought together into an organisation to achieve a general purpose without training taking place. There must be different types of training provided for managers, programmes should be developed for individual managers however a situation might arise from time to time for specific programmes for groups of managers; needs to be identified from the organisation's corporate plan or by an assessment.

Management development is a broad term, which includes individual career and skills development. Management development deals with recognizing, adopting, endorsing and using managers (Shen\& Darby, 2006). It is frequently considered essential for training managers who are supposed to be responsible for the future success of organisations (Mighty and Ashton, 2003). Although there are many purposes of MD; Winstanley et al (1996) identified five objectives of MD:

- A device should be made to engineer organisational change

- To approach following organisation achievement

- To change attitudes

- $\quad$ To assist in changing the role of line managers, and that

A tool should be created in search of quality, cost reduction and productivity (Winstanley et al., 1996).

However enthusiastic a training officer may be, MD is not something that can be achieved by extensive use of external courses. It is a long process involving forecasting, recruiting and promotion policies, training, appraisal, salary policies and even organisational planning (Roberts, 1974). As a result, MD has five basic principles: it is essentially providing the opportunity for managers to develop themselves. The process can only take place in a favourable organisation environment. MTD have similar purposes; the only differences between them are the learning methods used to implement them. For instance, MT is the use of session, lectures, and workshops, MD utilize learning centres, work rotation, and self-initiated. (Al-Khayyat \& Elgamal, 1997)

\section{MTDP in Libya}

Libya is an Arab Country, famously known as a gateway between Africa and western countries. It has a long Mediterranean Coast of about 2,000 km and occupies nearly 1,774,440 sqkms; with a population approximately of 5.7 million inhabitants, 5.3 are Libyan and the rest are from different nationalities (NBI \& D, 2006).Islam became the basic fact of life in Libyan society. The vast majority of Libyan's follow the Koran and the Hadith (the swords of Prophet Muhammad) (Gamal, 2008).

On 24th December 1951, Libya became an independent country referred to as the United Kingdom of Libya; although its economy was not performing well. It had budget deficits and was based on the limited productivity of a traditional agriculture sector. The discovery and exploration of oil after 1960 was the turning point; and the capital of the country increased rapidly; hence the increase in resources that transformed the economic performance significantly (Agnaia, 1997).

MTDP has not been considered as vital stage in Libyan organisations, as it was only introduced in the country after independence between 1953/54 to improve employee's skills and knowledge in the field of accounting and public administration. Subsequently the school of public administration was opened to train employees and impart managerial skills (Agnaia, 1997).

The government realized that education had to be developed because of the effects it had on all other aspects of life; with particular interest is management skills in organisation, with many management training and development centres established; some in partnership with international training and development centres. This follows the notion that, the need and importance of MTDP can only be seen in their role in developing individuals, by enhancing them with capacity and skills to improve their management efficiency. To date MTDPs have become one of the major challenges within the human resource management (HRM) or development effectiveness system in Libya.

Therefore, MTDPNA require more attention, as it is the key centre of the training and development cycle as follow:

- $\quad$ MTDP needs assessment (MTDPNA)

- $\quad$ Design and develop MTDP

- Deliver and implementation of MTDP

- Follow-up and evaluation of MTDP

Subsequently, MTDP stages are on-going processes that have been applied internationally in general, however very few studies have been carried out in Libya in particular. Therefore this paper will only look at MTDPNA in LPC, as a vital platform if implemented correctly within the selected organisations. 


\section{MTDPNA in Libya and the Arab region}

MTDPNA could be defined in Libya and Arab organisations as the most unconsidered stage of T\&D cycle in the past, as little studies addressed MTDPNA. For instance; Kuwaiti organisations do not use any systematic methods or approaches to implement training needs assessment, according to Abdalla and Al-Homoud in (1995).Agnaia (1996) point that, to implement training assessments in Arab organisations; the main sources must come from supervisors and participants.

Libya is one of the Arab countries, but very few empirical studies have investigated MTDPNA in the country of Libya. Agnaia (1996) found that, training needs assessment was exposed to the visions of bosses and supervisors rather than trainees themselves (managers or employees) in Libyan public sector and private organisations. Agnaia affirmed that, whoever is in charge of MTDPNA implementation sent their employees and managers to the programmes without any systematic approach, because they believed they were missing the skills and abilities to perform their tasks and duties.

Another empirical investigation by Etturki (1985) has found that, MTDPNA were conducted mostly at the lower managerial level rather than other senior level of management. (Agnaia, 1996; Etturki, 1985)

Other empirical literature on Jordan private and public sectors, found that, one-third of the organisations conducted MTDPNA at lower managerial level, but without practical and organisational analysis (Alhyasat, 2011; Altarawneh, 2009; and Abu-Doleh, 2005).

However, in the banking sectors, TNA was frequently conducted, represented by (77\%), and only (16\%) stated that their banking conduced TNA rarely.The banking organisations in Balqa Governorate in particular have highly conducted TNA to their employees (Alhyasat, 2011; Altarawneh, 2009; \& Abu-Doleh, 2005).

Thus, Training needs assessment consists of three level of analysis: organisation analysis; operations, task, or work analysis; and individual analysis (Yaw Chen \& Sok, 2007). Conducting a systematic needs assessment is a crucial initial step to training design and development and can significantly reflect to the overall effectiveness of training and development programmes (Arthur \& Bennett et al 2003).

Kaufumann, et al. (1993) suggest that the principle for needs assessment is to identify performance gaps, to prioritise them and to address the most significant ones, whereas needs analysis is to investigate the reasons for the gaps (Holton, et al., 2000)

Nowadays, MTDPNA has become the concern and very important aspect for every manager to develop personnel and institutions in Libya and the Arab region in general. That could help in identifying issues in the implementation and the follow-up of MTDP for more effectiveness (Abdel, 1991; and Muhammad \&Rashid, 2011, p.440). Therefore, MTDPNA need to form part of the organisations process in Libya and the Arab world organisations, and must be conducted on a methodical needs analysis basis.

MTDPNA can be effective if institutions embrace the working environment, as there are some factors both internal or externalthat can impact on the programmes negatively or positively even if MTDPNA was conducted correctly (Agnaia, 1996).

This paper will also look at some internal factors that might have some influence on MTDPNA such as; sectors, sizes, and the ownership of the organisations which will be discussed more within the results sections.

\section{Methodology}

In conducting this study, it was decided to look at NOIO in LPC in different sectors, size, and ownership. The conducted aiming to answer the following questions:

- What are the current MTDPNA applied within the NOIO in LPC?

- How MTDPNA was conducted and implemented?

- Was it effective?

To answer the above research questions, questionnaires were distributed to all managerial level in 28 NOIO in Libya between September 2011 and December 2011. A questionnaire is a data gathering tool that many researchers apply to collect required data.Gray (2006) \&Breakwell et al, (2000) define questionnaires as "research tools through which people are asked to respond to the same set of questions in a predetermined manner", and are useful for asking a large number of people. Questionnaires should be applied when they fit the objectives of the study tools (Gray, 2006\&Breakwell et al., 2000). 
19 out of 28 organisations participated in this study represent 71 managers (47.3\%) were from manufacturing (MS), 17 managers (11.3\%) were from construction sectors (CS), 26 managers (17.3\%) were from service sectors (SS), and 11 managers $(7.3 \%)$ were from hotel sectors (HS), as well as 25 managers $(16.7 \%)$ were from banking sectors (BS). $86 \%$ of them are joint venture organisations (Jvo); while others are international organisations (Io) represented by (14\%) respectively. In regards to size of the organisations, $38.7 \%$ of them were small sized organisations (S), $23.3 \%$ were medium organisations (M), and 38\% of organisations were large sized organisations (L).We distributed 237 questionnaires and 150 were completed.All managers in each organisation were asked about MTDPNA. The sample included $97.3 \%$ male and $8.7 \%$ female due to religious and background. Most of managers were Libyan nationality $(97.3 \%)$, and other nationals were represented (2.7\%) individually. $74.3 \%$ of managers were holding undergraduate certificate, followed by $35.3 \%$ with collage certificate. $36 \%$ of them were in head of department position, and $30.7 \%$ were supervisors. While only $12 \%$ were head of unite, and $21.3 \%$ were in senior positions.

The questionnaire of the study consists of two forms of questions: personal information and measurement questions. The collected dataset is analysed in a number of phases:

- The responses of questions are correctly recorded and categorized.

- The dataset was entered into computer via statistical package SPSS and checked by the researcher and volunteer for error issues.

A set of Likert scales was used to measure relevant concepts. The Likert scale is the most common, and it assesses the strength of the respondent's attitudes toward the subject area (Roberts, 1998). The reason behind using the scale is because this scale is well known in Libya and has been used in other studies in Libya; therefore using the same scale can help the researcher compare validity.

As a result, the researcher codes the responses accordingly: Strongly disagree $=1$ (STD), disagree $=2(\mathrm{D})$, uncertain $=3(\mathrm{U})$, agree $=4(\mathrm{~A})$, strongly agree $=5(\mathrm{STA})$.Using more than 5 will make respondents bored and it will take longer to answer the questions especially within the Libyan case.

The following shows how to define the extension of these scales, so that researcher can measure the response to each item. The extension is determined by $5-1=4$, and in order to identify the length of each scale (statement) the researcher compute $4 / 5=0.80$.Now, the upper limit for each cell is determined by adding 0.80 tothe code of agree, uncertain, disagree and strongly disagree. The following show the range of each scale; 1 to 1.80 strongly disagrees; 1.80 to 2.60 disagrees; 2.61 to 3.40 uncertain; 3.41 to 4.20 agree and 4.21 to 5.00 represents strongly agree.A pilot study was conducted and completed by academic and $\mathrm{PhD}$ students in order to ensure the validity of the questionnaire. Generally, the study approached the managers of the organisations to achieve credible outcomes.

Deferent SPSS statistical tests were applied in analysing the data to achieve findings, such as Wilcoxon signed ranks test, proportion test, and frequencies. However, the researcher highlights only the significant scores, which reflect the positive and the negative answers.

\section{Results}

As far as MTDPNA is concerned in this study, this section is divided into two main parts: first part of the section examines the current situation of MTDPNA in NOIO in LPC, and then looks at the conduction, methods, criteria, involvement on making decision of MTDPNA, the overall picture after MTDPNA in LPC. The second part investigates some factors that influenced MTDPNA in LPC positively or negatively.

\subsection{The Current MTDPNA in NOIO in LPC Situation}

The main appearances of the research participants by the questionnaires are analysed as follow:

Table 1. Table showingthe participants responcs rate in reagards to the conduction offormalMTDPNA

\begin{tabular}{llllllllllll}
\hline STD & D & & U & & A & & \multicolumn{3}{c}{ STA } & P-value \\
\hline F & P & F & P & F & P & F & P & F & P & $<0.001$ \\
3 & 2.0 & 21 & 14.0 & 16 & 10.7 & 71 & 47.3 & 39 & 26.0 & \\
\hline
\end{tabular}

Significant results was found as the p-value was $<0.05$

As can be presented from table 1, about 110 out of 150 (73.3\%) of the participants reported that their organisations conducted formal MTDPNA, and they adopted it annually represented (52\%) correspondents.

Although, these finding contradicts with other studies (Abdelgadir, 2001); itrevealed thatsmall and medium sized organisations sometimes do not see MTDPNA as an important aspect of MTDP, but large sized organisations view MTDPNA as a crucial step of the programmes. (Abdelgadir, 2001, pp.71-72) 
In support of the above finding, managers were asked which methods that their organisations used to implement MTDPNA. It has been cited that MTDPNA is done according to what department needs and face-to-face interview were the most applied methods $(68 \%)$. While group interview with the manager or supervisor and questionnaires were the least used methods (20\%); only $39.4 \%$ agreed with the methods, and the rest were either uncertain or disagreed (60\%).

Managers were also asked if they agreed with some criteria used for MTDPNA. The most common one was performance, experience and qualification. But individual interests were not taken in to organisations account as one of the important criteria applied. Grant (2002, cited by Yu-Hui et al., 2006, p.430) indicates that, individual interests are often used by some organisations that have a large number of workers to ask them to enrol to training courses. But this criterion is criticised for not being able to measure the truth, because sometimes employees write what they want, rather than what they need (In Yu-Hui et al., 2006, p.430).

Table 2. Table showing criteria used by their organisations to indicate the need for MTDPNA

\begin{tabular}{|c|c|c|c|c|c|c|c|c|c|c|c|}
\hline \multirow{2}{*}{$\begin{array}{l}\text { Criteria } \\
\text { lack of knowledge }\end{array}$} & \multicolumn{2}{|c|}{ STD } & \multicolumn{2}{|l|}{$\mathrm{D}$} & \multicolumn{2}{|l|}{$\mathrm{U}$} & \multicolumn{2}{|l|}{ A } & \multicolumn{2}{|c|}{ STA } & \multirow{2}{*}{$\begin{array}{l}\text { P-value } \\
<.001\end{array}$} \\
\hline & $\mathrm{F}$ & $\mathrm{P}$ & $\mathrm{F}$ & $\mathrm{P}$ & $\mathrm{F}$ & $\mathrm{P}$ & $\mathrm{F}$ & $\mathrm{P}$ & $\bar{F}$ & $P$ & \\
\hline & 14 & 9.3 & 0 & 0 & 13 & 8.7 & 44 & 29.3 & 19 & 12.7 & \\
\hline lack of skills & 1 & .7 & 8 & 5.3 & 15 & 10.0 & 48 & 32.0 & 23 & 15.3 & $<.001$ \\
\hline poor performance & 2 & 1.3 & 7 & 4.7 & 17 & 11.3 & 46 & 30.7 & 22 & 14.7 & $<.001$ \\
\hline introduction of new work method & 2 & 1.3 & 8 & 5.3 & 20 & 13.3 & 35 & 23.3 & 29 & 19.3 & $<.001$ \\
\hline low profitability & 10 & 6.7 & 21 & 14.0 & 29 & 19.3 & 13 & 8.7 & 6 & 4.0 & $<.001$ \\
\hline $\begin{array}{l}\text { frequent employees transfer to other } \\
\text { division }\end{array}$ & 10 & 6.7 & 29 & 19.3 & 20 & 13.3 & 14 & 9.3 & 6 & 4.0 & $<.001$ \\
\hline no criteria & 0 & 0 & 0 & 0 & 0 & 0 & 1 & .7 & 9 & 6.0 & $<.002$ \\
\hline
\end{tabular}

Significant results were found in some criteria as the p-value was $<0.05$

However, the researcher provided some criteria, and asked participants again if their organisations used them to specify MTDPNA as shows in table 2. According to the reply of participants to the above question, the most applied indicator by all organisations was lack of skills. This indicator was used by 47.3 per cent of the organisations. Another indicator used by 45.4 per cent of the organisations was poor performance.

Other indicators were applied by organisations ranged from 6.7 per cent to 42 per cent, as presented in table 2. (The percentage provided is the combination between strongly agreed and agreed)

In general, the most applied indicators were lack of skills, followed by poor performance. However, when poor performance in respects to the organisations performance as whole, cannot be an indicator for MTDPNA, since improving organisational performance has nothing to do with T\&DP (Altarawneh, 2005, p.229). Certainly, these organisations have to give more attention to the rest of the indicators to have an effective MTDPNA.

Table 3. Table showing if participants agree with the following statement "Providing MTDPNA to lower and middle level managers can increase their performance"

\begin{tabular}{llllllllllll}
\hline \multicolumn{2}{l}{ STD } & D & & U & & A & \multicolumn{3}{c}{ STA } & Median & P-value \\
\hline F & P & F & P & F & P & F & P & F & P & 4.0000 & $<0.001$ \\
2 & 1.3 & 6 & 4.0 & 25 & 16.7 & 73 & 48.7 & 43 & 28.7 & & \\
\hline
\end{tabular}

A significant result was found as the p-value was $<0.05$ and the Median were 4.0000

When the researcher asked all managers, what extent do you agree with the statement that "Providing MTDPNA to lower and middle level managers can increase their performance", participants replied their answers in different ways, which are presented in table 3 .

From the table 3, 48.7 per cent of managers agreed, and 28.7\% strongly agreed that providing MTDPNA to lower and middle managers can increase their performance, which has a clear indication that their top managements were 
supporting the above statement which can reflect positively to the organisational performance as whole. However, top management in organisations need to support all levels of managerial, and provide MTDPNA equally.

Table 4. Table showing the overall picture that the organisation has after implementation of MTDPNA

\begin{tabular}{lllllllllll}
\hline \multicolumn{2}{l}{ STD } & D & & U & & A & \multicolumn{3}{c}{ STA } & P-value \\
\hline F & P & F & P & F & P & F & P & F & P & .766 \\
5 & 3.3 & 34 & 22.7 & 46 & 30.7 & 52 & 34.7 & 12 & 8.0 & \\
\hline
\end{tabular}

Insignificant result was found as the p-value was $>0.05$

With regards to the overall picture of MTDPNA, managers were asked if they agreed with the overall picture after their organisations implement MTDPNA. The outcomes are provided in table 4.

The data in table 4 indicated that 42.7 per cent of managers agreed and strongly agreed with the overall picture in regards to MTDPNA. Another significant percentage, which has to be taken in consideration, was (30.7\%) of managers were uncertain if MTDPNA was effectively implemented or not.

\subsection{Factors that May Influence MTDPNA in NOIO in LPC Situation}

This paper as mentioned previously, also investigate factors that may influence MTDPNA positively or negatively in the post-crisis.

Therefore, MTDPNA can be more effective if organisations take internal or external factors into account. However, this paper will test the internal factors such as organisational sectors, size, and ownership that may influence MTDPNA negatively or positively. The researcher again analysed the same questions above to find out if there is any correlation between the factors and MTDPNA as presented below.

Table 5. Table summarising the results of the positive $\&$ the negative influence of all factors on MTDPNA

\begin{tabular}{llllll}
\hline Org Sectors Size,\& Ownership & No & Yes & Total & p-value & influences \\
\hline Direct observation. & & & & .032 & Positive \\
HS & 2 & 4 & 6 & & \\
Direct observation & & & & & \\
MS & 43 & 11 & 54 & .032 & Negative \\
CS & 12 & 1 & 13 & & \\
SS & 16 & 3 & 19 & & \\
BS & 15 & 2 & 17 & & \\
Jvo & 78 & 15 & 93 & .045 & \\
Io & 10 & 6 & 16 & & \\
Performance appraisal information or result. & & & & & Negative \\
MS & 43 & 1 & 54 & .042 & \\
CS & 10 & 3 & 13 & & \\
SS & 16 & 3 & 19 & & \\
HS & 5 & 2 & 7 & & \\
BS & 15 & 2 & 17 & & \\
S & 38 & 4 & 42 & .033 & \\
M & 15 & 5 & 20 & & \\
L & 46 & 2 & 48 & & \\
\hline
\end{tabular}

Association significant results was found whether positive or negative in some methods that were used by all organisations that influenced MTDPNA, as the p-values were $<0.05$

Direct observation was the only methods applied and influenced positively in hotel sectors in relation to sector influence, as they used this method more than any other methods to implement MTDPNA as shown in table 5. This answer was given when the researcher asked participants which methods their organisations used for MTDPNA. 
Chi-square crosstabs table test showed that, this method was highly statistically significant as the p-value was $(0.032)$ which is less than .05. This information seem to be consistent with a study done by Al-Ali, (1999) as he reported that, in Kuwait government sectordirect observation was one of the most used data collection methods in TNA (59.2\%).

Contrary to these results, Agnaia (1996) in his paper found out that, 71 and $51 \%$ of fourteen oil organisations in Libya were using MTDPNA methods based on documents, records, and consultation.

It could be argued that, only hotel sectors used direct observation as the data collection methods for MTDPNA, because hotel sectors have high level of employment, therefore, a big number of employments will make it hard for any organisations to monitor MTDPNA.

Whereas researcher tries to look at the negative side, direct observation and performance appraisal information or result were the two unimplemented approaches by the majority of the organisations in regards to the sectors, the size, and the ownership of the organisations. Similarly, a fieldwork research conducted by Agnaia observed that the selected organisations never use any systematic methods to identify MTDPNA; they were only using methods on documents, records, and consultation. (Agnaia, 1996)

Chi-square crosstabs table test presented that, performance appraisal information or result, and direct observation were statistically significant, as the p-value were $(0.032,0.045)$ and $(0.042$ and 0.033$)$ which were less than .05 .

In relation with the above finding, the researcher asked managers to rate to which they agree with criteria used MTDPNA. The finding indicated that the influence is positively strong in NOIO in Libya, in terms of experience, as managers strongly agreed and agreed that, their organisations within the ownership factor used experience as criterion for MTDPNA.

However, in regards to the other two factors (sectors and size) performance, experience, qualification, and individual interest were not the most used criteria in MTDPNA, which have negative influence on them.In supporting the negative influence finding, Grant (2002, cited by Yu-Hui et al., 2006, p.430) stated that, individual interest is criticised for not being able to measure the facts; as employees write what they want not what they need (in Yu-Hui et al., 2006).

Participants were asked to rate some criteria provided by the study based on how their organisation uses them to indicate MTDPNA.

Table 6. Table summarising the positive influence results of the criteria used by their organisations to indicate MTDPNA in relation to all factors

\begin{tabular}{|c|c|c|c|c|c|c|c|c|c|c|c|c|c|c|}
\hline & $\begin{array}{l}\text { Org } \\
\text { Sec, } \\
\text { Size } \\
\& \\
\text { Own }\end{array}$ & ST & & $\mathrm{D}$ & & $\mathrm{U}$ & & A & & Sta & & Median & P-value & influences \\
\hline \multirow{5}{*}{$\begin{array}{l}\text { Customer } \\
\text { dissatisfaction }\end{array}$} & & $\bar{F}$ & $P$ & $\bar{F}$ & $P$ & $\bar{F}$ & $P$ & $\mathrm{~F}$ & $\mathrm{P}$ & $\mathrm{F}$ & $P$ & & & \multirow[t]{12}{*}{ Positive } \\
\hline & M S & 2 & 2.8 & 6 & 8.5 & 19 & 26.8 & 8 & 11.3 & 0 & 0 & 3.0000 & .042 & \\
\hline & $\mathrm{C} \mathrm{S}$ & 1 & 5.9 & 3 & 17.6 & 7 & 41.2 & 2 & 11.8 & 0 & 0 & 3.0000 & & \\
\hline & S S & 0 & 0 & 2 & 7.7 & 6 & 23.1 & 2 & 7.7 & 2 & 7.7 & 3.0000 & & \\
\hline & B S & 0 & 0 & 4 & 16.0 & 5 & 20.0 & 3 & 12.0 & 2 & 8.0 & 3.0000 & & \\
\hline $\begin{array}{l}\text { Poor quality } \\
\text { service }\end{array}$ & $\mathrm{L}$ & 3 & 5.3 & 8 & 14.0 & 13 & 22.8 & 10 & 17.5 & 2 & 3.5 & 3.0000 & .018 & \\
\hline \multirow{2}{*}{$\begin{array}{l}\text { Low } \\
\text { profitability }\end{array}$} & S & 1 & 1.7 & 9 & 15.5 & 15 & 25.9 & 3 & 5.2 & 1 & 1.7 & 3.0000 & .044 & \\
\hline & $\mathrm{L}$ & 7 & 12.3 & 10 & 17.5 & 9 & 15.8 & 5 & 8.8 & 1 & 1.8 & 2.0000 & & \\
\hline \multirow{3}{*}{$\begin{array}{l}\text { Frequent } \\
\text { employees } \\
\text { transfer to } \\
\text { other division. }\end{array}$} & S & 2 & 3.4 & 11 & 19.0 & 7 & 12.1 & 6 & 10.3 & 3 & 5.2 & 3.0000 & .010 & \\
\hline & M & 0 & 0 & 4 & 11.4 & 4 & 11.4 & 6 & 17.1 & 1 & 2.9 & 3.0000 & & \\
\hline & $\mathrm{L}$ & 8 & 14.0 & 14 & 24.6 & 9 & 15.8 & 2 & 3.5 & 2 & 3.5 & 2.0000 & & \\
\hline $\begin{array}{l}\text { Lack of } \\
\text { knowledge }\end{array}$ & Io & 0 & 0 & 5 & 23.8 & 3 & 14.3 & 4 & 19.0 & 2 & 9.5 & 3.0000 & .035 & \\
\hline
\end{tabular}


Correlation was positively found in some criteria that were used in all organisations which influenced MTDPNA, as the p-values were $<0.05$

According to the response of managers to the question, table 6; indicated that the most common criteria used by all organisations were not clear as most managers were between uncertain and disagreed; if their organisations used some criteria as an indication for MTDPNA, which gave positive image to all organisations in relations to the influential factors.Customer expressed dissatisfaction with all sectors except hotel; highlighting poor quality service and low profitability by small and large sized organisations; with frequent employees transfer to other division by all sized organisations, and lack of knowledge by international organisations.

Two tests were used to examine the influence, which is Kruskal-Wallis Test to test the sectors and the size of organisations, and Mann-Whitney U test to test the ownership of the organisations, and all of them show significant p-value. But, from the negative perspective, no criteria were found as an indication for MTDPN.

Table 7. Table summarising the negative influence results of whom usually involved in decision to assess MTDPN in relation to all factors

\begin{tabular}{llllll}
\hline Org Sectors, Size, \& Ownership & No & Yes & Total & p-value & influences \\
\hline Your supervisor & 54 & 17 & 71 & .034 & Negative \\
MS & 12 & 5 & 17 & & \\
CS & 15 & 11 & 26 & & \\
SS & 9 & 2 & 11 & & \\
HS & 23 & 1 & 24 & & \\
BS & 104 & 24 & 128 & $<.001$ & \\
Jvo & & & & & \\
HR department & 58 & 13 & 71 & $<.001$ & \\
MS & 17 & 0 & 17 & & \\
CS & 23 & 3 & 26 & & \\
SS & 7 & 4 & 11 & & \\
HS & 11 & 13 & 24 & & \\
BS & 49 & 9 & 58 & .033 & \\
S & 21 & 13 & 34 & & \\
M & 46 & 11 & 57 & & \\
L & 96 & 32 & 123 & .038 & \\
Jvo & 20 & 1 & 21 & & \\
Io & & & & .025 & \\
Training manager & 93 & 35 & 128 & & \\
Jvo & 20 & 1 & 21 & & \\
Io & & & \\
\hline
\end{tabular}

Even though the p-values were $<0.05$, negative significant results were found, as not all managers were involved in making decision in regards to MTDPNA

No positive influence was found, but only negative influence was found in respects to the factors that might influence MTDPNA in NOIO in LPC, when managers were asked who is usually involved in the decision to assess MTDPNA as presented in table 7.

The crosstab chi-squared test shows that there were highly significant results where the p-value in (Your supervisor $=.034 \&<.001)$, (HR department $=<.001, .033, \& .038)$ and $($ Training managers $=.025)$. 
The majority of managers acknowledged that, supervisors in all organisational sectors and joint venture organisations were not involved in making decision for MTDPNA. Moreover, HR department was also not involved in all aspects ranging from; organisational sectors, size, and ownership. Whereas training managers in ownership of the organisations was negatively influenced, participants stated that their training managers were not involved as well for making decision to assess MTDPN.

This research demonstrates a clear focus on where MTDPNA are now within the selected organisations, indicating that, MTDPNA has become the main concern for all decision makers. This finding could be linked to some scholars as they suggest that frequently decision makers of organisations avoid TNA, as they believe that TNA is a costly approach to use. Nevertheless, not applying MTDPNA professionally is a huge mistake (Iqbal and Khan, 2011). Using MTDPNA will reduce the gap between the current practice of MTDP and desired performance. Hence, providing relevant programmes for managers can avoid the wastage of time and money.

\section{Conclusion}

From the argument of MTDPNA above, MTDPNA within LPC is the first and the most vital step of MTDP; with direct influence and effect on management development.

In the case of this study in NOIO in Libya, it is clear that questionnaire results indicate that the organisations performed some aspects of MTDPNA, because most Libyan organisations within the LPC were conducting MTDPNA regularly represented $(73.3 \%)$. That said, the methods, the implementation, the managers who are involved in making decision, and the criteria applied to indicate MTDPNA were not achieved systematically and effectively. In context of the above finding, Agnaia, (1996, p.17) revealed that, participants always criticize MTDP, as the content of the programmes are not matched to their needs. Participants mentioned that when organisations provide the programmes, they have to take into consideration participants needs to obtain organisational objectives more effectively. However, participant's interest is not always measure the reality; for managers occasionally draw down what they want rather than what they needs (Yu-Hui et al., 2006, p.430).

On the other hand, when the researchers look at the questions from another perspective, to see if factors such as; sectors, size, and ownership have influence on MTDPNA in the LPC or not; the finding indicated both positive and negative influences.

As a result, direct observation was the main method applied positively by hotel sectors; and experience was the only criteria used for MTDPNA by the ownership factor. However, the rest were negative and not implemented.

In regards to how organisations notice and indicates MTDPNA; the results revealed uncertainty and disagreement among most indicators which gave positive sign. But when the researchers asked participants about the involvement of making decision in regards to MTDPNA above, participants clearly stated that supervisors and HR department were not involved. Thus, lack of involvement of supervisors and HR department had negative impact on the organisation as a whole.

\section{Suggestions}

It is suggested that, methodological and systematic thinking within the decision makers in the current NOIO in Libya can perfectly lead to the right plan and implementation of MTDPNA.

Subsequently, the above finding led to the following suggestions:

- MTDPNA could be conducted at different times and used different methods and criteria to collect the relevant data rather than direct observation, performance appraisal information, and experience; which some organisations implement in order to comprehend any critical needs.

- $\quad$ Supervisors and HR department can be involved in making decisions in regards to MTDPNA based on systematic way rather than personal or group of individuals.

- MTDPNA could be provided to all management levels, rather than to only middle or lower managers.

To sum up, more attention should be given to MTDPNA in all NOIO in the LPC, which determine the gap between what is happening now and what is supposed to happen in future.Again, from the above finding, we can demonstrate that, lack of communication or involvement between managers who needs to be trained and the decision makers were noticed. Decision makers sometimes avoid MTDPNA, as they think that it is a costly approach to implement (Iqbal and Khan, 2011).

Therefore, If MTDPNA has not been explained and implemented professionally; MTDP can lead to costly mistakes. Therefore, NOIO in Libya have to have sort of bridge to discuss MTDPNA at all managerial levesl to obtained an effective MTDP. Abdalla, and Al-Homoud (1995) assert that "the absence of systematic needs assessment is serious 
drawback on the organisations' management development efforts .Needs assessment determines the gap between the current and desired performance and it is impossible for the organisations to improve competence without such knowledge. This knowledge may also help reduce training costs by placing managers on relevant programmes" (Abdalla, \& Al-Homoud, 1995, p.19)

\section{Limitation}

MTDPNA is the most crucial stage of the training cycle. This research has exposed only the recent MTDPNA situation in NOIO in the LPC and, further study can be extended to cover organisations under Libyan control, and oil organisations can be studied as well. External factors that may influence MTDPNA can be considered in future research. And finally this study reliance only on managerial level; further study can be implemented to address the entire population.

\section{References}

A speech by the Secretary of General People's for Economy (and Minister of Economy) in the International Conference on Trade and Investment, (2010), in Tripoli. [Online] available: http://www.libyaalyoum.com/look/article.tpl?IdLanguage $=17 \&$ IdPublication $=1 \& N r A r t i c l e=26563 \& N r I s s u e=1$ $\& \mathrm{NrSection}=3$ (April 1, 2010)

A speech from head of strategic projects in the Council for Privatization and Investment in an interview with Reuter's news agency, (2010), in Tripoli. [Online]Available:http://ara.reuters.com(April 2, 2010)

Abdalla, I.And Al-Homoud, M. (1995). "A Survey of Management Training And Development Practices In The State Of Kuwait", Journal Of Management Development, Vol. 14, No. 3, Pp. 14-25. http://dx.doi.org/10.1108/02621719510078939

Abdel Bari, D. (1991). Assessment of Training Needs within the Context of Administrative Reform in Jordan.International Journal of Manpower. 11(7): 3-10. http://dx.doi.org/10.1108/EUM0000000001702

Abu-Doleh, J. (2005). Management Training And Development Needs Assessment Practices In The Jordanian Private And Public Sectors: Integrated Or Isolated? Paper Presented At The Fourth Scientific Conference For Entrepreneurship And Innovation. Business Strategies In The Face Of The Challenges Of Globalization. Philadelphia University In Jordanian: 1-18.

Agnaia, A. A. (1996). Assessment Of Management Training Needs And Selection For Training: The Case Of Libyan Organisations .International Journal Of Manpower, 17, 31- 5. http://dx.doi.org/10.1108/01437729610119504

Agnaia, A.A. (1997). Management Training And Development Within Its Environment: The Case Of Libyan Industrial Organisations. Journal of European Industrial Training, 21, 117-123. http://dx.doi.org/10.1108/03090599710161829

Alhyasat, W. (2011). Impact The Effectiveness Of Training Programs On Job Performance: An Application To Banks In Balqa Governorate. MBA, Faculty Of Graduate Studies At The University Of Balqa.

Al-Khayyat, R., M. \& Elgamal, M., A. (1997). A Macro Model Of Training And Development: Validation. Journal Of European Industrial Training, 21, 87-101. http://dx.doi.org/10.1108/EUM0000000000812

Al-Khayyat, R. (1998). "Training And Development Needs Assessment: A Practical Model For Partner Institutes", Journal Of European Industrial Training, Vol. 22 No. 1, Pp. 18-27. http://dx.doi.org/10.1108/03090599810197658

Altarawneh, I. (2009). Training And Development Evaluation In Jordanian Banking Organizations. Research And Practice In Human Resource Management, 17(1), 1-23.

Anderson, V. \& Gilmore, S. (2010). Learning, Experienced Emotions, Relationships And Innovation In Hrd. Journal Of European Industrial Training, 34, 753-771. http://dx.doi.org/10.1108/03090591011080959

Arthur, Jr.W.; Bennett Jr, W; Pamela, S; Edens\& Suzanne, T. B. (2003). Effectiveness Of Training In Organissations: A Meta-Analysis Of Design And Evaluation Features, American Psychological Association, Inc, 88 (2), Pp.234-245.http://dx.doi.org/10.1037/0021-9010.88.2.234

Breakwell, G.M; Hammond, S. \& Fife-Schaw, C. (2000). Research Methods In Psychology, $2^{\text {nd }}$ Ed,. London: Sage Publications 
De.Silva, S. (1997). Human Resources Development For Competitiveness: A Priority For Employers'. Paper Presented At The ILO Workshop On Employers' Organisations In Asia-Pacific In The Twenty-First Century. [Online] Available: http://www.ilo.org/public/english/dialogue/actemp/downloads/publications/srshrd.pdf

Dowling, P.J. And Welch, D. (2004). International Human Resources Management: Managing People In Multinational Context, 4th Ed., Thomson Learning, London.

Earley, P.C. And Peterson, R.S. (2004). "The Elusive Cultural Chameleon: Cultural Intelligence As A New Approach To Intercultural Training For The Global Manager", Academy Of Management Learning And Education, Vol. 3 No. 1, Pp. 10015.

Eid, F., \& Fiona, P., (2003). Foreign Direct Investment in the Arab World: The Changing Investment Landscape, in P.K. Kornelius and K. Schwab (eds.): The Arab World Competitiveness Report, World Economic Forum, Oxford University Press

Enshassi, A \& Burgess, R. (1990). Training for construction site managers involved with multicultural work teams, Butterworth \& Co (Publishers) Ltd,May 1990, 18(2), pp. 0263-7863/90/02009547. http://dx.doi.org/10.1016/0263-7863(90)90043-B

Etturki, M.S. (1985). Management Development And Organisational Effectiveness In Developing Countries With Special Reference To Libya (SPLAJ). Phd Thesis University Of Southern California.

Gamal, N .S. (2008). How to Attract Foreign Direct Investment to Invest in Housing in Libya, PhDthesis, University of Salford, Salford, UK

Gary, D. E. (2006). Doing Research in the Real World. London: Sage Publications

Graf, A. (2004b). "Expatriate Selection: An Empirical Study Identifying Significant Skill Profiles", Thunderbird International Business Review, Vol. 46 No. 6, Pp. 667-85. http://dx.doi.org/10.1002/tie.20030

Hartungi, R. (2006). Could Development Countries take the Benefit of Globalisations? , International Journal of Social Economics, Emerald Group Publishing Limited, 33 (11), pp.728-743. http://dx.doi.org/10.1108/03068290610705652

Holton, E., Bates, R. and Naquin, S. (2000). Large-scale Performance driven Training Needs Assessment: A Case Study, Public Personnel Management, 29 (2), pp.249- 268.

Jiraphan, S. (2000). International Join Venture Negotiation Behaviour and outcome: the Role of bargaining Power, Culture and Trust (Qualitative Case Studies), PhD thesis, City University, London, UK.

Koenig, N. (2011). The EuAndThe Libyan Crisis-In Quest Of Coherence? The International Spectator, 46, 11-30. http://dx.doi.org/10.1080/03932729.2011.628089

Littrell, L.N. and Salas, E. (2005). "A Review Of Cross-Cultural Training: Best Practices, Guidelines, and Research Needs", Human Resource Development Review, Vol. 4 No. 3, Pp. 305-34. http://dx.doi.org/10.1177/1534484305278348

Muhammad Zahid, I. \& Rashid Ahmad, K. (2011). The Growing Concept And Uses Of Training Needs Assessment: A Review With Proposed Model. Journal of European Industrial Training, 35, 439-466. http://dx.doi.org/10.1108/03090591111138017

National Board for Information and Documentation, (2006). [Online] Available: http://www.geohive.com/cntry/libya.aspx (May 22, 2012)

Reitsma, S, G. (2001). Management Development in Unilever, Journal of Management Development, Emerald, 120 (2), pp. 131-144. http://dx.doi.org/10.1108/02621710110382150

Piyali, G., Jagdamba Prasad, J., Rachita, S., Udita, M. \& Rashmi, R. (2011). Evaluating Effectiveness of A Training Programme With Trainee Reaction. Industrial And Commercial Training, 43, 247-255. http://dx.doi.org/10.1108/00197851111137861

Political Risk Yearbook: Libya Country Report. (2009). Preceding pU-1-16, 61p, 17 charts, 7 graphs, 1 map; (AN 36117860)

Privatization \& Investment Board (PIB) [Online] Available: http://www.investinlibya.ly/sites/pagesEn/Default.aspx (October 11, 2012 
Privatization \& Investment Board $\quad$ (PIB) [Online] Available: http://www.investinlibya.ly/PDF/LawNo5ExcutiveEnglish.pdf(October 11, 2012)

Privatization \& Investment Board (PIB) Amended to Law No (9) by the Libyan Government, (2010), [Online] Available: http://investinlibya.ly/PDF/Law9.pdf(October 11, 2012)

Selmer, J. (2000). "A Quantitative Needs Assessment Technique for Cross-Cultural Work Adjustment Training”, Human Resource Development Quarterly, Vol. 11 No. 3, Pp. 269-81. http://dx.doi.org/10.1002/1532-1096(200023)11:3<269::AID-HRDQ5>3.0.CO;2-6

Shen, J. \& Darby, R. (2006). Training and Management Development In Chinese Multinational Enterprises. Employee Relations, 28, 342-362. http://dx.doi.org/10.1108/01425450610673402

Stewart, J. (1996). Quoted In:Younes, A. (2007). The Appointment Of New Managers In Libyan Post And The Impact On Existing Employees, MBA Dissertation, University Of Central Lancashire.

Stone, R.D. (2009). Aligning Training for Results: A Process And Tools That Link Training To Business, Pfeiffer Publishing, San Francisco, CA.

Tarique, L. And Caligiuri, P. (2004). “Training And Development Of International Staff”, In Harzing, A. And Jay, V.R. (Eds), International Human Resource Management, Sage, Thousand Oaks, CA, Pp. 283-306.

Whetherly, J. (1998). Achieving Change through Training and Development, Library Association Publishing.

Winstanley, D., Woodall, J. \&Heery, E. (1996). Business Ethics And Human Resource Management: Themes And Issues. Personnel Review, 25, 5-12. http://dx.doi.org/10.1108/00483489610148491

Yaw Chen, C. \& Sok, P. (2007). Exploring Potential Factors Leading To Effective Training: An Exclusive Study On Commercial Bank In Cambodia, Journal Of Management Development, Emerald, 26 (9), Pp. 843. http://dx.doi.org/10.1108/02621710710819339

Yu-Hui, T., Yeh, C. R. \& Sheng, I. S. (2006). Improving Training Needs Assessment Processes Via The Internet: System Design And Qualitative Study. Internet Research, 16,427-449. http://dx.doi.org/10.1108/10662240610690043 